\title{
PENGARUH MCKENZIE BACK EXERCISE TERHADAP PENURUNAN SKALA NYERI HAID (DISMINORE) DI SMK NEGERI 1 KUBUTAMBAHAN
}

\author{
(Effect of McKenzie Back Exercise Toward Dysmenorrhea in Female Student At \\ Senior High School Of 1 Kubutambahan)
}

\author{
I Made Sundayana ${ }^{1}$, Ni Putu Diantari ${ }^{2}$, Kadek Yudi Aryawan ${ }^{3}$ \\ Program Studi S1 Keperawatan, Sekolah Tinggi Ilmu Kesehatan Buleleng \\ e-mail: madesundayana@gmail.com
}

\begin{abstract}
ABSTRAK
Pendahuluan: Dismenore merupakan nyeri pada perut bagian bawah yang dialami sewaktu menstruasi. Nyeri dapat dirasakan sebelum atau selama mengalami menstruasi dan biasanya dismenore akan berlangsung selama satu atau dua hari. Dismenore disebabkan karena peningkatan hormon prostaglandin dan terjadi kontraksi otototot Rahim yang menegang. Sebagian besar remaja putri mengalami dismenore pada punggung bagian bawah, pinggang, pinggul, hingga otot paha atas. Tujuan dari penelitian ini yaitu untuk menganalisis pengaruh mckenzie back exercise terhadap dismenore siswi SMK Negeri 1 Kubutambahan. Metode: desain penelitian ini yaitu pra eksperimental dengan rancangan one group pre post test design. Besar sampel yang digunakan yaitu 55 responden yang telah dipilih dengan menggunakan teknik purposive sampling. Pengumpulan data dilakukan menggunakan lembar observasi nyeri Bourbonnais. Penelitian ini menggunakan uji Paired t-test dengan tarah signifikan $\alpha=0,05$. Hasil : Didapatkan hasil data nilai rata-rata pre 4,15 dan niali rata-rata post 2,65. Hasil uji menggunakan uji Paired t-test didapatkan nilai $\mathrm{p}(0,000)<\alpha(0,05)$, artinya $\mathrm{H}_{0}$ ditolak dan $\mathrm{H}_{\mathrm{a}}$ diterima. Sehingga disimpulkan ada Pengaruh Mckenzie Back Exercise Terhadap Skala Nyeri Haid Di SMK Negeri 1 Kubutambahan.
\end{abstract}

Kata kunci: Mckenzie Back Exercise, Nyeri Haid (Dismenore)

\begin{abstract}
Introduction: Dyssmenorrhea is a pain in the lower abdomen which appear during menstruation. Pain may be felt before or during menstruation and usually dysminorrhea will gone after one or two days. Dysmenorrhea is caused by the increased prostaglandin hormone and the contraction of the uterus muscle. Most girls experience dysmenorrhea in the lower back, waist, hips, until the upper tight muscle. The purpose of this study was to analyze the effect of mckenzie back exercise twoward dysmenorrhea in female student at senior high school of 1 Kubutambahan. Method: The research design was pre experimental design with one group pre post test design. The sample is used 55 respondent who have selected by using purposive sampling technique. The date from respondent were collected using an observation sheet bourbonnais. This study used Paired t-test with a significant level of $\alpha=0.05$. Results: Obtained the results of the average value of pre 4.15 and the mean value of the post 2,65. Test results using the Paired t-test $p$ value $(0.000)<\alpha(0.05)$, meaning that $H_{0}$ is rejected and ${ }_{H a}$ is accepted. So it was concluded that there is Effect of mckenzie back exercise toward dysmenorrhea in female student at senior high school of 1 Kubutambahan.
\end{abstract}

Keywords: Mckenzie Back Exercise, Dysmenorrhea

\section{PENDAHULUAN}

Remaja merupakan suatu proses tahapan dari masa anak-anak menuju pendewasaan. Masa remaja atau pubertas, merupakan dimana masa ini menjadi penghubung antara masa anak-anak dengan masa dewasa. Pertumbuhan dan perkembangan pada masa remaja sangat pesat, baik secara fisik maupun secara psikologis, perkembangan ini berlangsung pada usia 11-16 tahun pada laki-laki dan 10-15 tahun pada perempuan. Perkembangan pada masa puber dipengaruhi oleh hormone seksual yaitu progesterone dan estrogen, organ-organ reproduksi telah mulai berfungsi, salah 
satu tanda dari masa pubertas adalah mulai terjadinya menstruassi pada perempuan (Proverawati Atikah \& Misaroh Siti, 2009).

Pubertas adalah tahapan yang sangat penting dalam perkembangan seksualitas. Pubertas dimulai pada saat usia 8-14 tahun dan berlangsung kurang lebih selama 4 tahun dan berakhir pada saat ovarium sudah berfungsi secara mantap dan teratur. Masa pubertas khususnya pada perempuan, dapat timbul tanda-tanda pertumbuhan badan yang cepat, perubahan psikis, dan timbulnya ciri-ciri kelamin sekunder seperti tumbuhnya rambut pada daerah pubis, pembesaran payudara dan terjadi menstruasi (Proverawati Atikah \& Misaroh Siti, 2009).

Menstruasi merupakan perdarahan yang terjadi pada uterus yang dimulai sekitar 14 hari setelah terjadinya ovulasi. Menstruasi merupakan perdarahan vagina secara berkala yang diakibatkan oleh lepasnya lapisan endometrium uterus, yang terjadi secara rutin setiap bulannya selama masa subur kecuali terjadi kehamilan. Darah menstruasi akan mengalir dari Rahim menuju ke leher Rahim lalu keluar melalui vagina. Perdarahan menstruasi memiliki panjang siklus 28 hari yang durasi menstruasinya selama 2-7 hari.

Disminore merupakan suatu keadaan nyeri yang dirasakan pada bagian bawah perut pada saat mengalami siklus menstruasi (Ratnawati, 2018). Kata disminore berasal dari Bahasa Yunani dys yang berarti nyeri, kesulitan atau abnormal, sedangkan meno artinya bulan, dan rhea berarti aliran. Jadi dapat diartikan bahwa dismenore adalah suatu keadaan sakit atau keabnormalan pada saat menstruasi yang dirasakan oleh wanita setiap bulannya dimana hal ini ditandai dengan aliran atau keluarnya darah pada vagina (Sukarni \& Wahyu, 2013).
Angka kejadian dismenore di dunia masih tinggi, menurut data World Health Organisation (WHO) tahun 2017 didapatkan bahwa angka kejadian dismenore sebesar 1.769.425 (90\%) jiwa. Angka kejadian dismenore di setiap Negara dilaporkan masih sangat tinggi, dengan rata-rata lebih dari $50 \%$ wanita di setiap Negara mengalami dismenore, prevalensi dismenore di Amerika Serikat pada tahun 2012 pada wanita usia 12-17 tahun adalah $59,7 \%$ dengan derajat $49 \%$ dismenore ringan, $37 \%$ dismenore sedang, dan $12 \%$ dimenore berat yang mengakibatkan $23,6 \%$ dari penderitanya tidak mengikuti pembelajaran di sekolah. Pada tahun 2012 didapatkan sebanyak $75 \%$ remaja wanita di Mesir mengalami dismenore, 55,3\% dismenore sedang, dan $14,8 \%$ yang mengalami dismenore berat (Nurwana, Sabilu, \& Fachlevy, 2017).

Banyak penanganan yang dapat dilakukan untuk mengatasi dismenore, baik secara farmakologi maupun non farmakologi. Secara farmakologi menggunakan berupa obat-obatan, sedangkan non farmakologi merupakan suatu terapi tanpa menggunakan obat melainkan dengan cara tradisional ataupun dengan latihan fisik seperti kompres hangat, senam dismenore, jogging, dll (Anurogo, 2018).

McKenzie merupakan suatu teknik latihan dengan menggunakan gerakan badan terutama pada bagian belakang/ekstensi, biasanya digunakan untuk menguatkan dan meregangkan otototot ekstensor dan fleksor sendi lumbasacaralis dan dapat mengurangi nyeri Metode latihan yang digunakan ini untuk meminimalisir rasa nyeri yang dirasakan oleh pekerja khusunya pekerja yang tergolong berat (Robin McKenzie, 2014).

Dari penelitian yang dilakukan oleh Fitrihadi (2017) tentang "Pengaruh Penguatan Otot Transversus Abdominis Terhadap Nyeri Menstruasi Pada Mahasiswa Kebidanan Universitas 
Aisyiyah Yogyakarta" didapatkan hasil bahwa ada pengaruh yang signifikan dalam pemberian terapi transversus abdominis exercise terhadap nyeri haid. Dan berdasarkan penelitian yang dilakukan oleh (Nuraeni, 2017) "Pengaruh Senam Dismenore Terhadap Penurunan Nyeri Pada Remaja Putri SMK 1 Tapango Kecamatan Tapango Kabupaten Polewali Mandar" didapatkan hasil bahwa ada pengarur yang signifikan sebelum dan sesudah pemberian senam dismenore dengan nilai (p) 0,000 yang artinya $p<\alpha$, dengan nilai $<0,05$.

Berdasarkan studi pendahuluan yang dilakukan oleh peneliti di SMK Negeri 1 Kubutambahan pada tanggal 7 Januari 2019, hasil wawancara dengan staf kurikulum didapatkan data bahwa jumlah siswi kelas 10 dari dua jurusan yaitu farmasi dan pariwisata 112 orang, kemudian hasil wawancara yang dilakukan bersama siswi didapatkan bahwa yang mengalami disminore sebanyak 64 orang atau 57,14\%. Setelah dilakukan wawancara dan observasi bersama 9 orang siswi yang sedang mengalami dismenore pada saat itu, terdapat 5 orang yang mengatakan nyeri sedang $(55,5 \%)$, kemudian ada 3 orang yang mengatakan nyeri ringan $(33,3 \%)$, dan 1 orang yang mengatakan nyeri berat $(11,1 \%)$.

Berdasarkan uraian diatas maka peneliti tertarik untuk mengangkat judul penelitian "Pengaruh McKenzie Back Exercise Terhadap Penurunan Skala Nyeri Haid Di SMK Negeri 1 Kubutambahan".

Alat yang digunakan untuk mengumpulkan data pada penelitian ini berupa lembar observasi Bourbonnais untuk mengukuran skala nyeri. Lembar observasi tersebut berisi data demografi responden terdiri dari nama, umur, jurusan dan alamat. Pada pengukuran skala nyeri menggunakan format penilaian Bourbonnais yang berbentuk lembar observasi untuk mengetahui skala nyeri haid (dismenore)

\section{METODE PENELITIAN}

Penelitian ini menggunakan penelitian pre eksperimental, karena dalam penelitian memberikan perlakuan atau intervensi pada objek yang akan diteliti. Desain yang digunakan dalam penelitian ini yaitu One Group Pre-Test dan Post-Test, dimana objek yang akan diteliti sebelum diberikan perlakuan dilakukan pre-test terlebih dahulu dan setelah diberikan perlakuan atau intervensi akan dilakukan post-test (Nursalam, 2015). Penelitian ini dilakukan di SMK Negeri 1 Kubutambahan.

\section{HASIL PENELITIAN DAN PEMBAHASAN}

Sampel penelitian ini adalah siswi kelas $\mathrm{X}$ yang mengalami nyeri haid (dismenore) yang sudah memenuhi kriteria inklusi yang berjumlah 55 orang. Adapun karakteristik sampel penelitian ini adalah sebagai berikut:

Tabel 1. Karakteristik Responden Berdasarkan Kelompok Usia Di SMK Negeri 1 Kubutambahan.

\begin{tabular}{ccccccc}
\hline $\begin{array}{c}\text { Variab } \\
\text { el }\end{array}$ & N & Mean & $\begin{array}{l}\text { Mi } \\
\mathbf{n}\end{array}$ & $\begin{array}{l}\text { M } \\
\mathbf{a x}\end{array}$ & SD & $\mathbf{9 5 \%}$ CI \\
\hline Umur & 55 & 16,38 & 15 & 1 & 0,68 & $16,20-$ \\
& & & & 8 & 0 & 16,57 \\
\hline
\end{tabular}

Hasil analisis univariat karakteristik responden berdasarkan tabel 1 bisa disimpulkan bahwa usia termuda dari responden yaitu 15 tahun dan usia tertua yaitu 18 tahun, dari 55 responden rata-rata (mean) usia responden yaitu 16,38 dengan standar deviation 0,680 .

Tabel 2. Karakteristik Responden Berdasarkan Jurusan Di SMK Negeri 1 Kubutambahan.

\begin{tabular}{ccc}
\hline Jurusan & Frekuensi & Persentase \\
\hline AP1 & 17 & 30,9 \\
\hline AP2 & 10 & 18,2 \\
\hline AP3 & 6 & 10,9 \\
\hline Farmasi 1 & 10 & 18,2 \\
\hline Farmasi 2 & 12 & 21,8 \\
\hline Total & 55 & 100 \\
\hline
\end{tabular}

http://ejournal.stikesbuleleng.ac.id/index.php/Midwinerslion | 66 
Berdasarkan tabel 2 bisa disimpulkan bahwa siswi yang mengalami nyeri dismenore paling banyak yaitu terdapat dijurusan akomodasi perhotelan 1 sebanyak 17 oranng $(30,9 \%)$, dan yang paling sedikit yaitu terdapat dijurusan akomodasi perhotelan 3 sebanyak 6 orang $(10,9 \%)$ dari 55 responden dalam penelitian.

Tabel 3. Uji Normalitas Data

\begin{tabular}{lccc} 
& Satistic & Standar error & Hasil Bagi \\
\hline $\begin{array}{l}\text { Sebelum } \\
\text { Intervensi }\end{array}$ & 0,205 & 0,322 & 0,637 \\
$\begin{array}{l}\text { Setelah } \\
\text { Intervensi }\end{array}$ & $-0,138$ & 0,322 & $-0,429$ \\
\hline
\end{tabular}

Berdasarkan table 3 di atas menunjukan bahwa hasil bagi skeweness dengan standar error baik sebelum maupun sesudah pemberian intervensi keduanya kurang dari 2 dimana data yang berdistribusi normal didapat dari hasil bagi skeweness dengan standar error harus $<2$ sehingga dapat disimpulkan bahwa kedua data di atas berdistribusi normal.

Tabel 4. Skor Nyeri Dismenore Di SMK Negeri 1 Kubutambahan Sebelum Diberikan Intervensi Mckenzie Back Exercise.

\begin{tabular}{lllllll}
\hline & $\mathbf{N}$ & Mean & $\begin{array}{l}\text { Mi } \\
\mathbf{n}\end{array}$ & $\begin{array}{l}\text { M } \\
\mathbf{a x}\end{array}$ & SD & $\mathbf{9 5 \%} \mathbf{C I}$ \\
\hline Pre test & 55 & 4,15 & 2 & 6 & $\begin{array}{l}1,11 \\
3\end{array}$ & $3,84-4,45$ \\
\hline
\end{tabular}

Berdasarkan table 4 menunjukan bahwa rata-rata (mean) skor nyeri haid (dismenore) sebelum diberikan terapi mckenzie back exercise dari 55 siswi yaitu 4,15 (95\% CI 3,84-4,45), dengan standar deviation 1,113 . Skor nyeri haid terendah yaitu 2 dan yang tertinggi yaitu 6, dari estimasi interval dapat disimpulkan bahwa 95\% diyakini bahwa rata-rata tingkat nyeri haid pada siswi SMK Negeri 1 Kubutambahan yaitu 4,45.

Tabel 5. Skor Nyeri Dismenore Di SMK Negeri 1 Kubutambahan Sesudah
Diberikan Intervensi Mckenzie Back Exercise.

\begin{tabular}{|c|c|c|c|c|c|c|}
\hline & $\mathbf{N}$ & Mean & Mi & $\begin{array}{l}\text { M } \\
\text { ax }\end{array}$ & SD & 95\% CI \\
\hline Pre test & 55 & 2,65 & 1 & 4 & $\begin{array}{l}0,96 \\
6\end{array}$ & $2,39-2,95$ \\
\hline
\end{tabular}
menunjukan bahwa rata-rata (mean) dari skor nyeri haid setelah diberikan intervensi atau terapi mckenzie back exercise dari 55 responden 2,65 (95\% CI 2,39-2,95), dengan standar deviation 0,966 , skor nyeri haid terendah yaitu 1 dan yang tertinggi yaitu 4. Estimasi interval dapat disimpulkan bahwa 95\% diyakini bahwa rata-rata tingkat nyeri haid pada siswi SMK Negeri 1 Kubutambahan yaitu 2,92.

Tabel 6. Analisis Bivariat Pengaruh Terapi McKenzie Back Exercise Terhadap Skala Nyeri Haid (Dismenore).

\begin{tabular}{|c|c|c|c|c|}
\hline \multirow[b]{2}{*}{$\begin{array}{c}\text { variabe } \\
1\end{array}$} & \multirow[b]{2}{*}{$\mathbf{N}$} & \multirow[b]{2}{*}{$\begin{array}{c}\text { Mean\&S } \\
\text { D }\end{array}$} & \multicolumn{2}{|c|}{$\begin{array}{c}\text { Paired } \\
\text { differences }\end{array}$} \\
\hline & & & $\begin{array}{l}\text { Perbedaan } \\
\text { (Mean\&SD) }\end{array}$ & $\mathbf{p}$ \\
\hline Pre test & 55 & $\begin{array}{c}4,15 \& \\
1,113\end{array}$ & $\begin{array}{c}1,491 \& 0,54 \\
0\end{array}$ & $\begin{array}{c}0,00 \\
0\end{array}$ \\
\hline Pos test & 55 & $\begin{array}{c}2,65 \& \\
0,966\end{array}$ & & \\
\hline
\end{tabular}

Berdasarkan tabel 6 di atas menunjukan hasil uji yang dilakukan dengan menggunakan uji paired t-test menunjukan bahwa sig. (2-tailed) atau nilai $p$ value $=0,000$, karena nilai $p$ lebih kecil dari 0,05 maka hipotesis nol $\left(\mathrm{H}_{0}\right)$ ditolak dan hipotesis alternative $\left(\mathrm{H}_{\mathrm{a}}\right)$ diterima. Sehingga dapat disimpulkan bahwa ada pengaruh mckenzie back exercise terhadap nyeri haid di SMK Negeri 1 Kubutambahan.

\section{KESIMPULAN}

Karakteristik responden berdasarkan umur dari 55 orang responden didapatkan bahwa umur termuda adalah 15 tahun dan umur tertua adalah 18 dengan rata-rata 16,38 tahun. Karakteristik responden berdasarkan jurusan dapat disimpulkan sebagaian besar responden berada di http://ejournal.stikesbuleleng.ac.id/index.php/Midwinerslion | 67 
jurusan akomodasi perhotelan 1 dengan jumlah 17 orang $(30,9 \%)$, dan jumlah terendah berada di jurusan akomodasi perhotelan 3 dengan jumlah 6 orang $(10,9)$.

Berdasarkan hasil pengukuran skala nyeri sebelum melakukan mckenzie back exercise dapat disimpulkan bahwa dari 55 orang responden yang diteliti terdapat sebelum diberikan terapi rata-ratanya 4,15 dengan standar deviasi 1,113. Nilai skala terendah adalah 2 dan tertinggi adalah 6 .

Berdasarkan hasil pengukuran skala nyeri setelah diberikan intervensi, 55 orang responden setelah diberikan terapi McKenzie back exercise dengan rata-rata skala nyeri menjadi 2,65 dengan standar deviasi 0,966 dan nilai skala terendah yaitu 1 dan tertinggi 4.

Hasil uji analisa data dengan menggunakan uji Paired t-test menunjukan bahwa nilai $\mathrm{p}<\alpha \quad(0,000<0,05)$ dengan demikian hipotesis nol $\left(\mathrm{H}_{0}\right)$ ditolak. Penelitian ini membuktikan adanya Pengaruh mckenzie back exercise terdapat penurunan skala nyeri haid di SMK N 1 Kubutambahan.

\section{SARAN}

1. Berikanlah dukungan dan fasilitas yang memadai untuk mahasiswa dalam melakukan suatu kegiatan atau penelitian. Semoga penelitian ini bisa dijadikan refrensi di perpustakaan.

2. Bagi siswi yang ada di sekolah SMK Negeri 1 Kubutambahan diharapkan dapat memberi atau berbagi informasi mengenai gerakan ini yang bisa menghilangkan nyeri haid sehingga banyak yang bisa melakukannya.

3. Bagi perkembangan ilmu keperawatan diharapkan nantinya menggunakan kelompok control agar hasil yang didapat lebih ektif dan lebih signifikan, dan mampu menemukan teori-teori baru untuk mengatasi masalah kesehatan lainnya.

4. Bagi peneliti selanjutnya disarankan untuk menggunakan desain penelitian yang menggunakan group control, sehinggan hasil yang didapat lebih signifikan.

\section{REFERENSI}

Anurogo, D., \& Wulandari, A. (2011). Cara Jitu Mengatasi Nyeri Haid. Yogyakarta: C.V Andi Offset.

Donsu, T. D. J. (2016). Metodologi Penelitian Keperawatan. Yogyakarta.

Fitriahadi, E., Daryanti, S. M., \& Sulistyaningsih. (2017). Pengaruh

Penguatan Otot Transversus Abdominis Terhadap Nyeri Menstruasi Pada Mahasiswa Kebidanan Universitas Aisyiyah Yogyakarta, 40-48.

Jannah, N., \& Rahayu Sri. (2017). Kesehatan Reproduksi \& Keluarga Berencana. Jakarta: EGC.

Kuala, S. (2016). Penurunan Tingkat Nyeri Saat Menstruasi Melalui Latihan Abdominal Stretching The Menstruation Pain Level Decline By Abdominal Stretching Exercise memberikan perhatian yang serius terhadap ( latihan fisik ) dapat mengatasi dismenore dan kegiatan atau aktiv.

Kumalasari, I., \& Andhyantoro, I. (2012). Kesehatan Reproduksi Untuk Mahasiswa Kebidanan dan Keperawatan. Jakarta: Salemba Medika.

Laila Najmi Nur. (2011). Buku Pintar Menstruasi. Yogyakarta: BukuBiru.

McKenzie, R. (2014). 7 Step To A Pain. New York: LLC.

Notoatmodjo, S. (2012). Metodologi Penelitian Kesehatan. Jakarta: Rineka Cipta.

Nuraeni. (2017). Pengaruh Senam Dismenore Terhadap Penurunan Nyeri Pada Remaja Putri SMK 1 Tapango Kecamatan Tapango Kabupaten Polewali Mandar. Jurnal Ilmiah Bidan, 2(1).

Nursalam. (2015). Metodologi Penelitian Ilmu Keperawatan (Edisi 4). Jakarta: Salemba Medika. 
Padila. (2014). Keperawatan Maternitas. Yogyakarta: Nuha Medika.

Proverawati Atikah, \& Misaroh Siti. (2009). Menarche. Yogyakarta: Nuha Medika.

Ramano, A. (1981). Mckenzie Method.

Ratnawati, A. (2018). Asuhan Kperawatan Pada Pasien Dengan Gangguan Sistem Reproduksi. Yogyakarta: Pustaka Baru Press.
Siswanto, Susila, \& Suyanto. (2016). Metodologi Penelitian Kesehatan Dan Kedokteran. Yogyakarta: Bursa Ilmu.

Sugiono. (2017). Statistik Untuk Penelitian. Bandung: ALFABETA.

Sukarni, I., \& Wahyu. (2013). Keperawatan Maternitas. Yogyakarta: Nuha Medika. 